\title{
An Analysis of the Durability of Resistance to Plant Viruses
}

\author{
Fernando García-Arenal and Bruce A. McDonald
}

First author: Departamento de Biotecnología, E.T.S. Ingenieros Agrónomos, Universidad Politécnica de Madrid, E-28040 Madrid, Spain; and second author: Institute of Plant Sciences, Phytopathology Group, ETH Zentrum/LFW, Universitätstrasse 2, CH-8092 Zürich, Switzerland. Accepted for publication 5 March 2003.

\begin{abstract}
García-Arenal, F., and McDonald, B. A. 2003. An analysis of the durability of resistance to plant viruses. Phytopathology 93:941-952.

Genetic resistance often fails because a resistance-breaking (RB) pathogen genotype increases in frequency. On the basis of an analysis of cellular plant pathogens, it was recently proposed that the evolutionary potential of a pathogen is a major determinant of the durability of resistance. We test this hypothesis for plant viruses, which differ substantially from cellular pathogens in the nature, size, and expression of their genomes. Our analysis was based on 29 plant virus species that provide a good representation of the genetic and biological diversity of plant viruses. These

29 viruses were involved in 35 pathosystems, and 50 resistance factors deployed against them were analyzed. Resistance was found to be durable more often than not, in contrast with resistance to cellular plant pathogens. In a third of the analyzed pathosystems RB strains have not been reported, and in another third RB strains have been reported but have not become prevalent in the virus population. The evolutionary potential of the viruses in the 35 pathosystems was evaluated with a compound risk index based on three evolutionary factors: the population of the pathogen, the degree of recombination, and the amount of gene and genotype flow. Our analysis indicates that evolutionary potential may be an important determinant of the durability of resistance against plant viruses.
\end{abstract}

Over the nearly 100 years since Biffen described the Mendelian nature of the resistance of plants to pathogens (6), a major objective of plant breeding has been to develop cultivars resistant to pathogens. Genetic resistance is the favored control strategy, as it may be highly effective and organism-specific and has minimal deleterious effects on the environment. The advantages of resistance are countered by the ability of pathogen populations to evolve and overcome the protection conferred by the resistance factors; i.e., resistance has often been short-lived. This has been most often documented for resistance determined by genes with major phenotypic effects and Mendelian inheritance, particularly in pathosystems that follow a gene-for-gene relationship. The result is a classic boom-and-bust cycle, best documented for rusts and powdery mildews of cereals (see the literature cited in reference 87). Understanding the factors that affect the durability of resistance and devising strategies to increase durability have been primary goals in plant pathology research over the last 50 years.

Recently, McDonald and Linde $(87,88)$ analyzed the durability of resistance to a large number of plant pathogens and proposed that the main factor determining durability is not the nature of the resistance genes but rather the evolutionary potential of the pathogen population. They used a simple model in which each of three evolutionary forces was assigned three levels of risk, to develop an index of "predicted risk" that would quantify the evolutionary potential of the pathogen. The three analyzed evolutionary forces were population size, gene and genome flow (i.e., migration), and reproduction or mating system (i.e., sexual or asexual). Population size affects the probability that a mutant will appear in a population and will be present in subsequent generations. In small popu-

Corresponding author: F. García-Arenal; E-mail address: fga@bit.etsia.upm.es

* The e-Xtra logo stands for "electronic extra" and indicates that the online version contains supplemental material not included in the print edition. The online supplement presents detailed information on the pathosystems analyzed, showing how risk categories were assigned and how breakdown or durability of resistance was determined.

Publication no. P-2003-0523-01R

(C) 2003 The American Phytopathological Society lations the fate of mutants is affected by a random process called genetic drift. Drift depends on the effective size of the population (i.e., the number of individuals that pass their genes to the next generation) and not on the census size (i.e., the total number of individuals in the population). Gene and genome flow is the process through which genes, or whole genomes in pathogens that do not recombine, are exchanged between different populations. A high degree of gene flow increases the probability that resistancebreaking (RB) strains may come into contact with resistant plants. Finally, sexual reproduction will favor the spread in the pathogen population of the gene or genes involved in resistance breaking by recombining mutant alleles into genetic backgrounds that may have higher fitness. Two other forces, mutation and selection, were not quantified. Interestingly, McDonald and Linde (87) found a significant correlation between predicted risk based on gene flow and observed risk based on the durability of resistance. No viral pathogens were included in their analyses.

Viruses are second only to fungi in the number and economic importance of the diseases they cause. Chemical control of plant viruses is not commercially feasible, so genetic resistance is preferred for the control of viral diseases. Hence, it is useful to determine if the model of McDonald and Linde also applies to plant viruses. Two main differences between viruses and cellular pathogens with regard to plant resistance add interest to this analysis: (i) resistance to plant viruses is not predominantly inherited as a monogenic dominant character, unlike resistance to other plant pathogens (37); (ii) resistance to viruses has often been more durable than resistance to cellular pathogens (50).

We analyze here the durability of resistance to a set of phytopathogenic viruses with a range of life histories, applying the procedure of McDonald and Linde (87). Our results show that, as with cellular pathogens, the evolutionary potential of the virus seems to be a major determinant of the durability of resistance.

\section{THEORY AND APPROACHES}

The model proposed by McDonald and Linde (87) was applied with minor modifications. As described earlier (87), we did not consider mutation or selection in our analysis. Most plant viruses 
have RNA genomes, or their genomes replicate by reverse transcription of an RNA template (57). It is well known that mutation rates in RNA viruses are several orders of magnitude higher than those of microbes with DNA genomes $(29,82)$. However, it is not known if mutation rates of plant viruses with small, single-stranded DNA (ssDNA) genomes are similar to those of RNA viruses or to those of animal or bacterial viruses with large, double-stranded DNA (dsDNA) genomes. Variability in field populations points to the first possibility (51). Since our data set included only viruses with RNA or small ssDNA genomes, we did not attempt to differentiate between mutation rates of RNA and DNA plant viruses. Selection was not considered because resistant varieties make up a large fraction of the crop in all pathosystems considered and should have resulted in relatively uniform and strong selection for resistance-overcoming variants.

Three categories of risk were assigned to each of the three evolutionary forces, by the following logic.

(I) Effective population size. This important parameter has not been estimated reliably for any plant virus. In spite of the large number of viruses produced in an infected plant, the effective population size in the host could be several orders of magnitude smaller than the census population, as shown for the animal virus HIV-1 $(39,80)$. In addition, population bottlenecks are expected to occur during the process of infection of a new host or following the seasonal population dynamics of the virus's hosts and vectors. It is well known that a small number of virus particles is sufficient to start an infection in a naïve host (40) and that insect vectors carry a small number of virus particles (106). The reduction in population size will be proportional to the size of the bottleneck that affects the virus population between crop seasons. Thus, differences in effective population size are likely to be associated with the population dynamics of the host and vectors, as they affect the ability of the virus to survive at the site, sensu Harrison (50), in the absence of the crop. Viruses can survive in seeds and other plant parts, in plant debris, in soil, in vectors, and in other hosts. For instance, severe bottlenecks will occur between seasons

TABLE 1 . Viruses analyzed in this work

\begin{tabular}{|c|c|c|c|}
\hline Acronym & Name & Genus & Genome $^{a}$ \\
\hline ACMV & African cassava mosaic virus & Begomovirus & ssDNA (2) \\
\hline CMV & Bean common mosaic virus & Potyvirus & $(+)$ ssRNÁ (1) \\
\hline CTV & Beet curly top virus & Curtovirus & ssDNA (1) \\
\hline BLRV & Bean leafroll virus & Luteovirus & (+) ssRNÁ (1) \\
\hline BNYVV & Beet necrotic yellow vein virus & Benyvirus & (+) ssRNA (4-5) \\
\hline BYDV & Barley yellow dwarf virus & Luteovirus & $(+)$ ssRNA (1) \\
\hline $\mathrm{LCuV}$ & Cotton leaf curl virus & Begomovirus & A (1) \\
\hline MV & Cucun & Сuc & A (3) \\
\hline RV & Groundnu & Umbravirus & 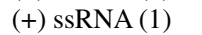 \\
\hline MV & Lettuce mosaic virus & Potyvirus & $(+)$ ssRNA (1) \\
\hline NSV & Melon $r$ & & \\
\hline $\mathrm{CV}$ & $M a$ & $M a$ & \\
\hline PEMV & $P e$ & Ena & (2) \\
\hline PMMoV & nild mottle virus & Tobamovirus & (+) ssRNA (1) \\
\hline PShMV & Pea seed-borne mosaic virus & Potyvirus & $(+)$ ssRNA (1) \\
\hline VY & & & \\
\hline PVY & Pot & Pot & $(+)$ \\
\hline RGSV & Rice & Tenuivirus & (-) ssRNA (6) \\
\hline RpRSV & Raspberry ring spot virus & Nepovirus & $(+)$ ssRNA (2) \\
\hline & Rices & Tenuivirus & 4-5) \\
\hline RTSV & Rice & Waik & $(+) s$ \\
\hline SBWMV & Soil-bor & Furo & $(+) \mathrm{ss}$ \\
\hline SMV & Soybea & Poty & (+) ssRNA (1) \\
\hline TBRV & Tomato black ring virus & Nepovirus & (+) SSRNA (2) \\
\hline TM & Tobacco mosaic virus & Tobamovir & $(+)$ ssRNA (1) \\
\hline ToMV & Tomato & Tobamovirus & $\mathrm{JA}(1)$ \\
\hline & Tom & Tospovirus & (-) ssRNA (3) \\
\hline TYLCV & Tomato yellow leaf curl virus & Begomovirus & ssDNA (1) \\
\hline TuMV & Turnip mosaic virus & Potyvirus & $(+)$ ssRNA (1) \\
\hline
\end{tabular}

${ }^{a}$ Single-stranded DNA (ssDNA) or single-stranded RNA (ssRNA) genome of messenger polarity $(+)$ or negative polarity $(-)$, with the number of genomic segments in parentheses. in the population of a virus that has a narrow host range, is transmitted by aphids in a nonpersistent manner, and is not seed-transmitted, because of the lack of hosts in which to survive. In these cases we assigned risk category 1 . Bottlenecks will not be as severe for a virus that has a large host range (or if the primary host is grown all year round) and that can survive in a vector with a large and stable population (e.g., in the resting spores of a fungal vector) or that is efficiently transmitted on seed. In these cases we assigned risk category 3 . The intermediate risk category 2 was assigned, for instance, to viruses that have narrow host ranges but a high rate of survival in seeds or in vectors with stable populations and viruses that do not survive in seeds or vectors but have a large number of overwintering hosts. In these analyses we do not consider the experimental host range of a virus, but rather the natural host range shown to be epidemiologically significant for the crop. For instance, the experimental host range of Tobacco mosaic virus is very large, but in practice tobacco is the only inoculum source for tobacco crops (45), and here it is considered a virus with a narrow host range.

(II) Gene and genotype flow. This factor quantifies the rate of migration among populations and, hence, the dispersal potential of a virus. We rated this factor differently than McDonald and Linde (87). Risk category 1 was assigned to viruses that disperse over a range of meters to kilometers (e.g., viruses that are soilborne or dispersed by contact or by vectors flying only short distances). Risk category 2 was assigned to viruses that disperse over a range of about 10 to $100 \mathrm{~km}$ (e.g., viruses that are persistently transmitted by flying vectors). Risk category 3 was assigned to viruses that are able to disperse hundreds or thousands of kilometers (e.g., viruses that are mainly seedborne or otherwise dispersed by humans or that persist in their long-distance-dispersing vectors). The risk categories were assigned by the use of epidemiological data or, preferentially, data on the genetic structure of the virus population, when available.

(III) Reproduction system. Here we considered viruses for which sex, sensu Chao (17), i.e., genetic exchange, has not been reported (risk category 1) and viruses for which it has been reported to occur by reassortment of genomic segments or by recombination, reassortants and recombinants being frequent (risk category 3 ) or not frequent (risk category 2) in the viral populations. If only reassortants have been described, we placed the virus in risk category 2. Available evidence indicates that the interchange of complete genomic segments has a bigger impact on the fitness of a virus than the exchange of genes or parts of genes and will be more affected by negative selection. Indeed, most evidence points to co-adaptation of genomic segments (42). The frequency of recombinants or reassortants in virus populations has been analyzed in only a few viral systems. Information from nucleotide sequences in data banks was used for some viral systems, but for the remaining systems information was not available. When information was lacking, we used the available knowledge for other virus species in the same genus. Genetic exchange can be detected easily if the parents differ sufficiently in nucleotide sequence. The main limitation in analyzing the frequency of recombinants is that recombination between genetically similar parents may result in a different phenotype but will not be detected as a recombinant because its sequence is too similar to that of the parents.

For all analyzed pathosystems we considered the virus population in a defined geographic region. This is relevant because agroecological conditions that can influence the evolutionary factors described earlier may differ in different regions.

Viral pathosystems analyzed. A detailed review of the literature retrieved data on the three evolutionary factors and on the use, duration, and nature of resistance in a number of pathosystems. Data were collected for 29 viruses (Table 1). Five had ssDNA genomes, three had ssRNA genomes of negative polarity ( - sense), and 21 had ssRNA genomes of messenger polarity (+ sense). This data set is a good representation of the groups of plant viruses 


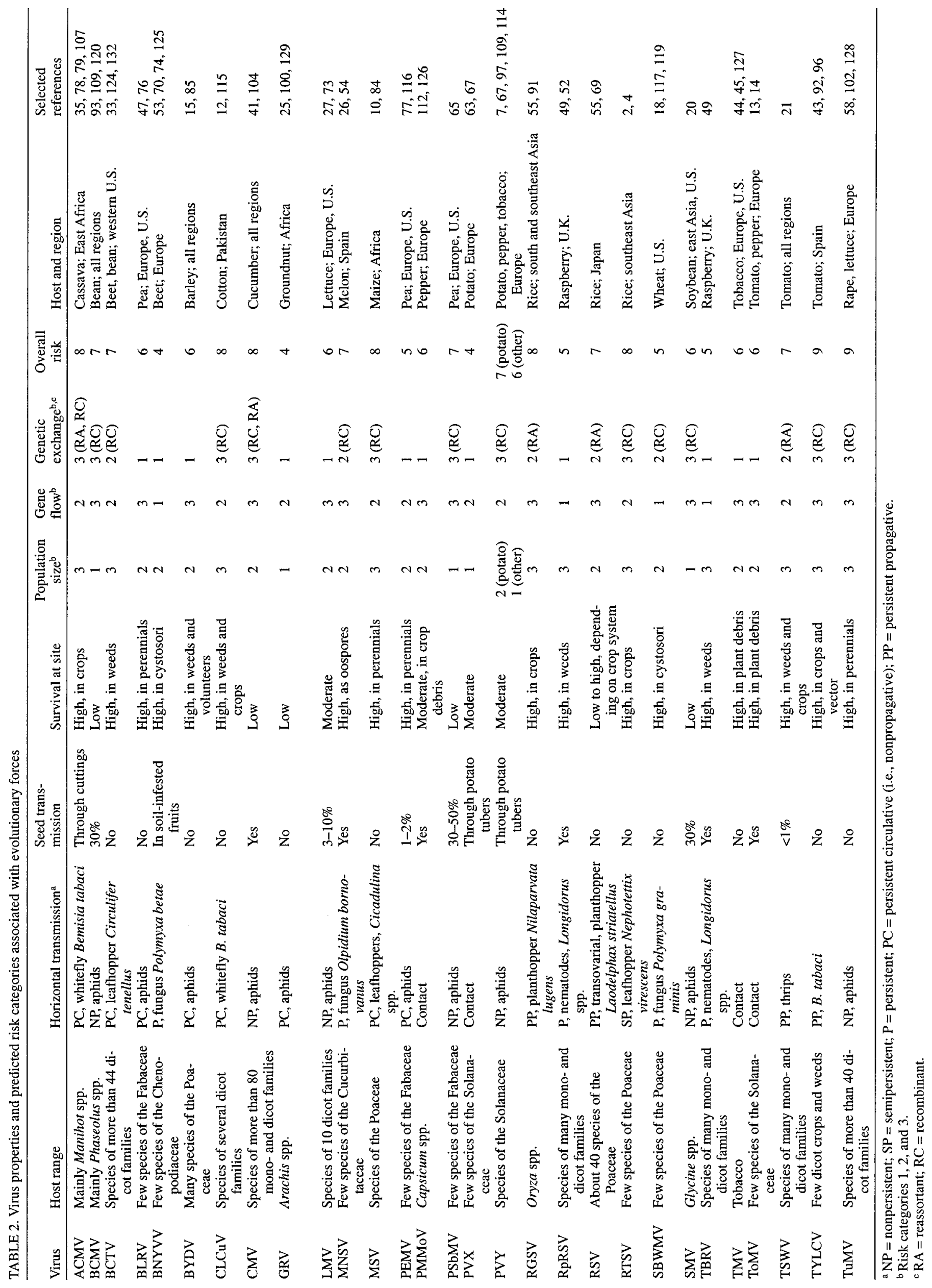




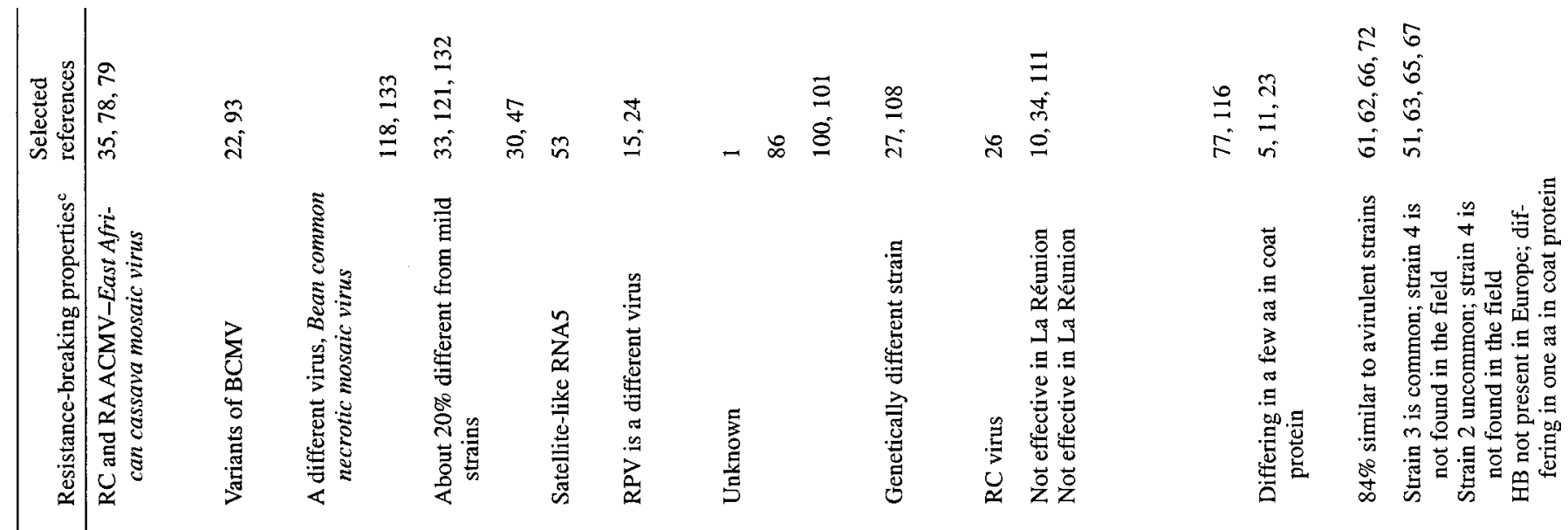

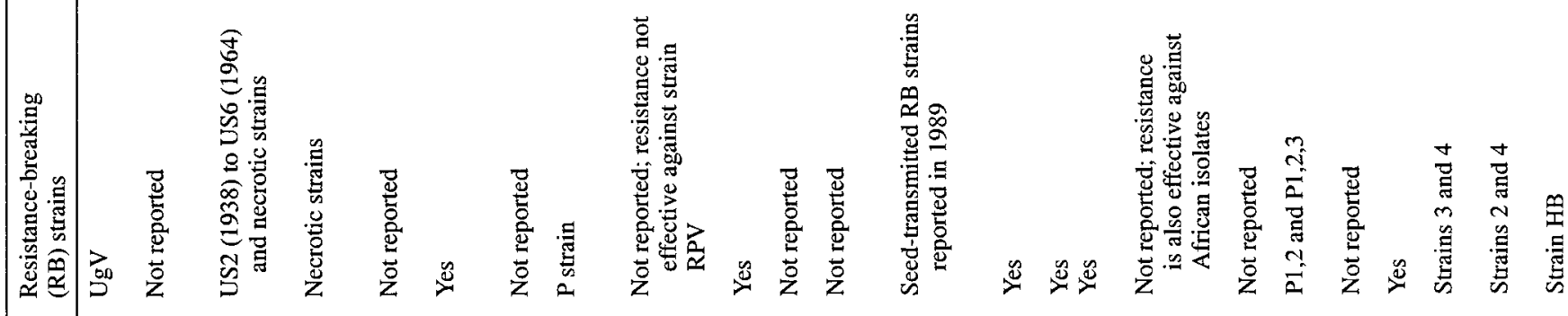

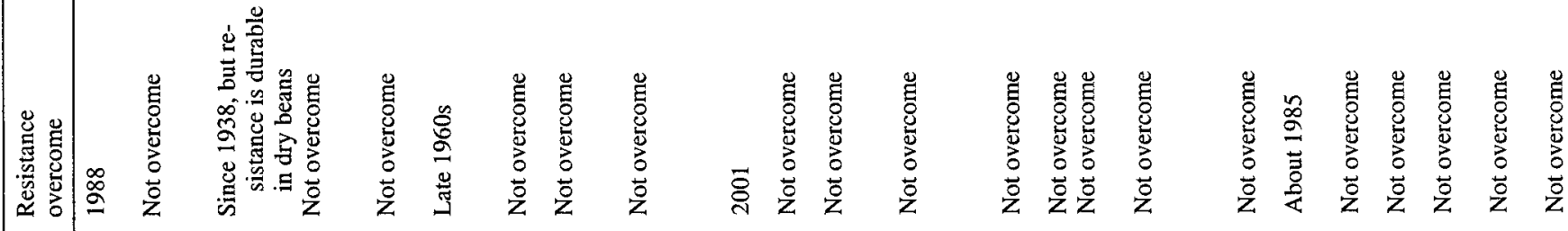

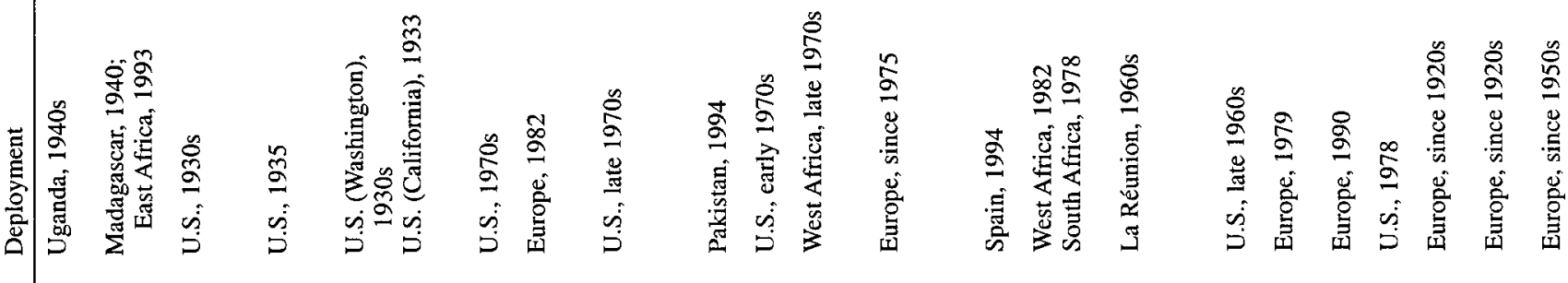

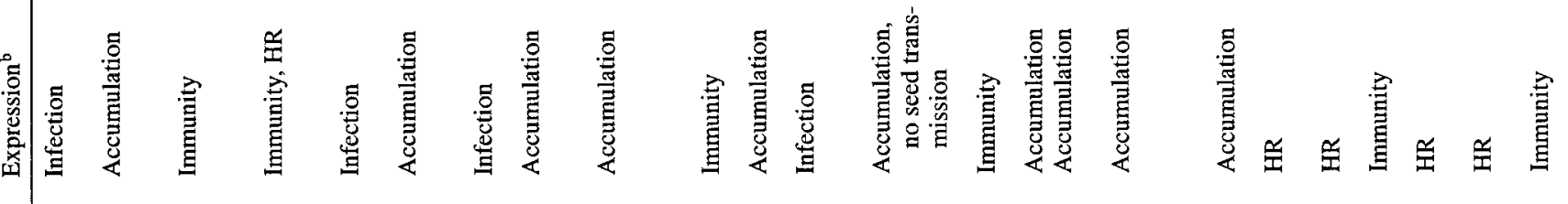

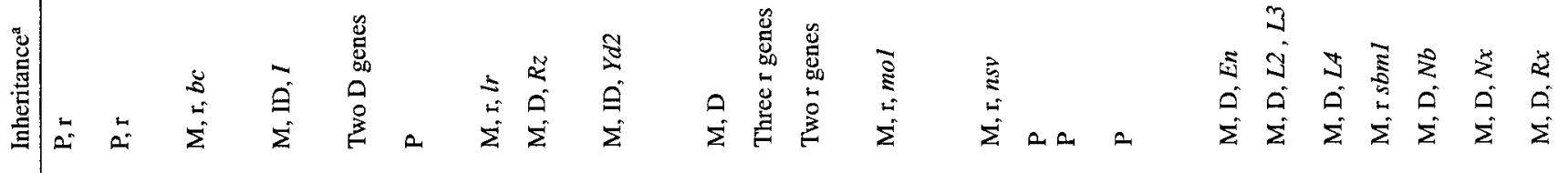

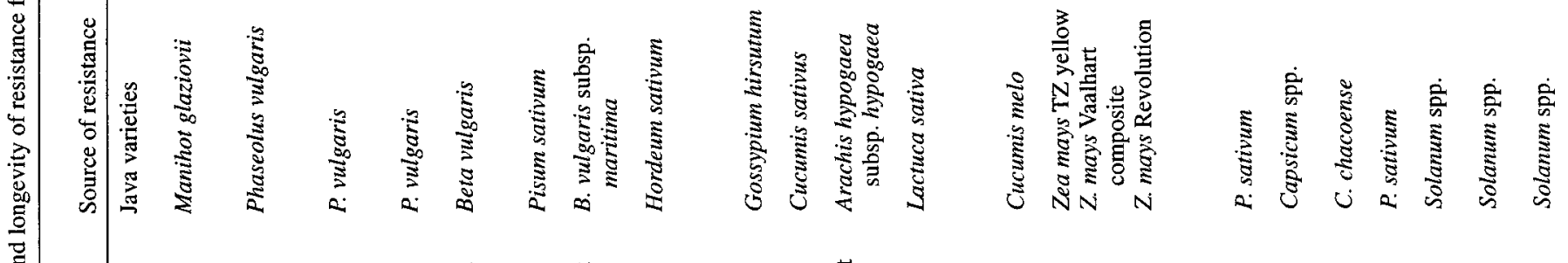

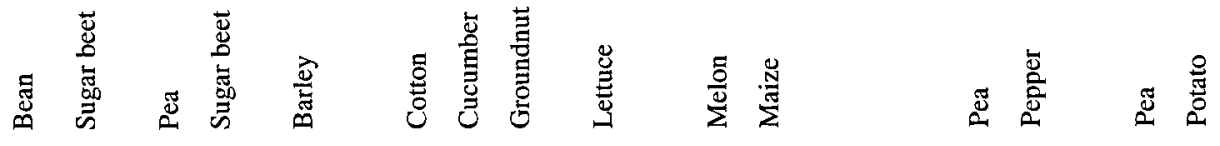

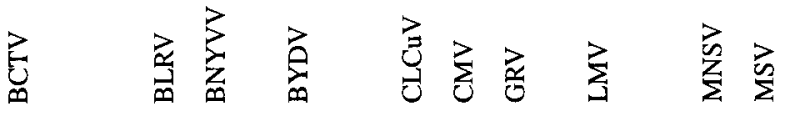

虽意意学 


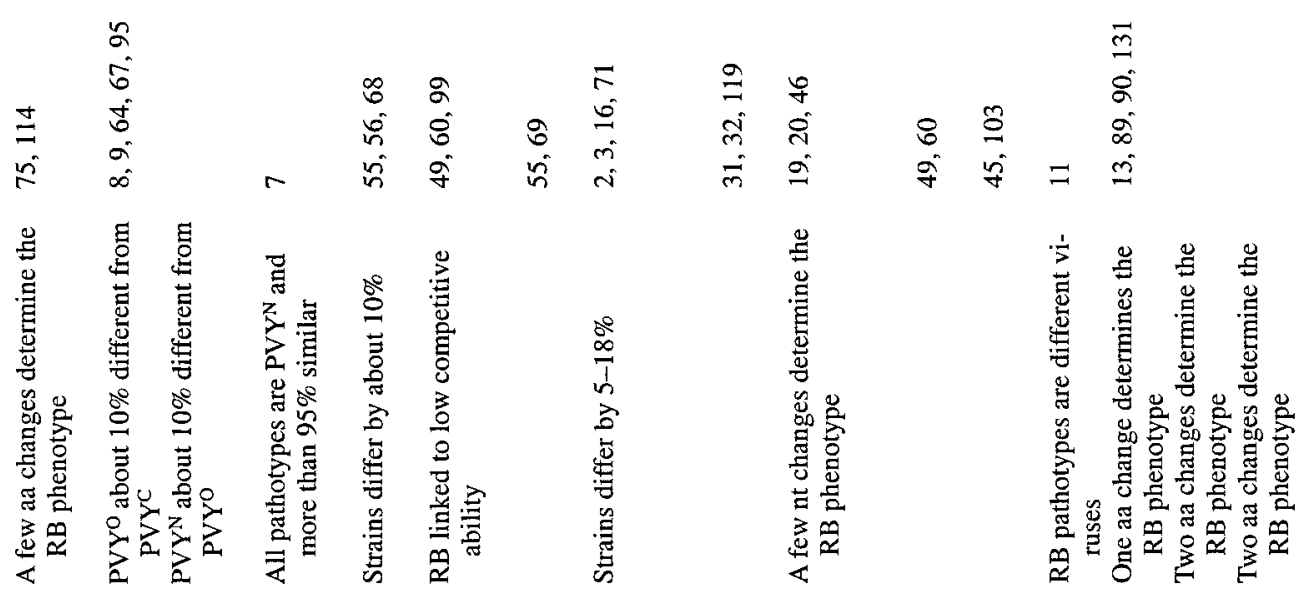

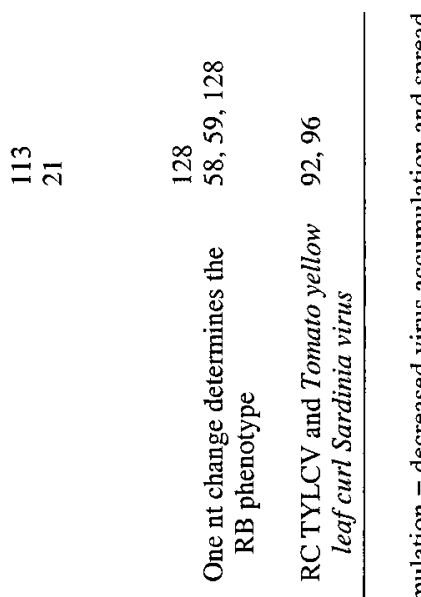

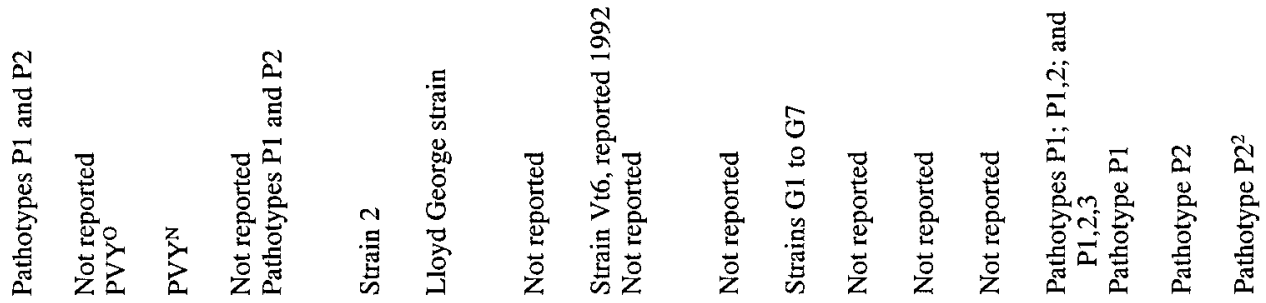

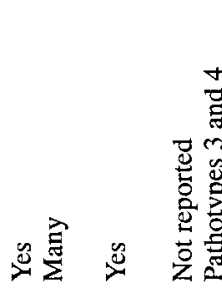

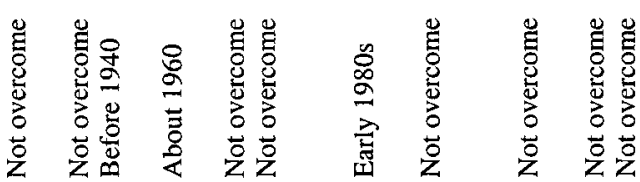

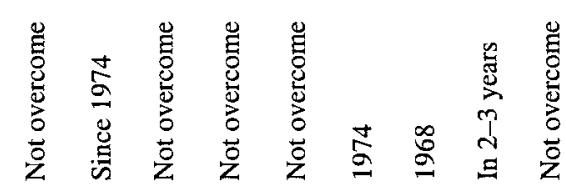

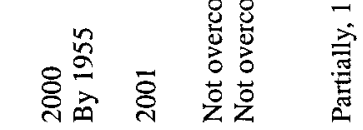

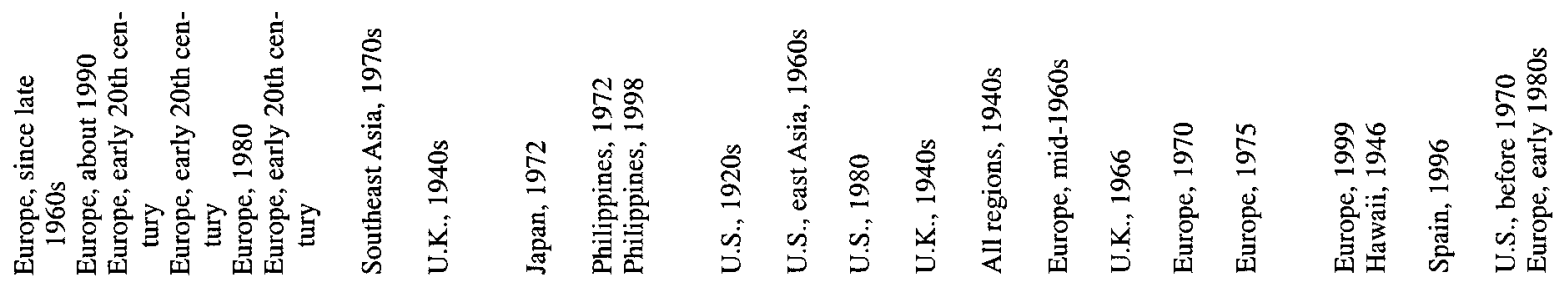

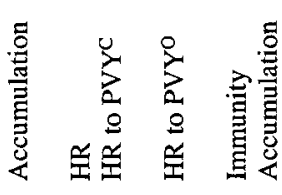

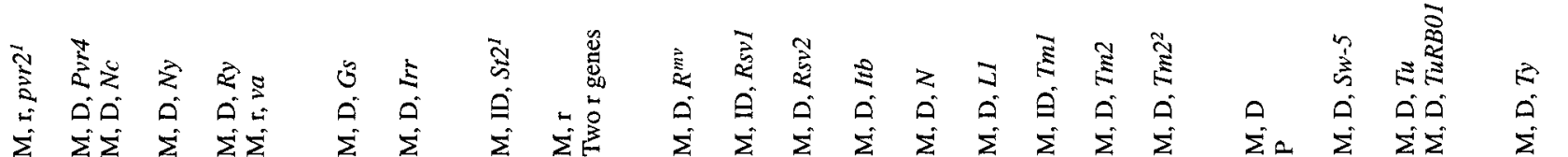

IIIIn

差

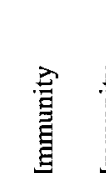

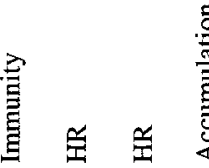

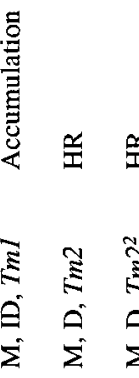


according to the nature of their genetic material, except that no examples were found of viruses having dsRNA genomes or viruses having dsDNA genomes and replicating by reverse transcription. The data set also included a wide range of transmission strategies. Five viruses were transmitted by contact, 13 by aphids (seven in a nonpersistent manner), three by whiteflies, five by leafhoppers or planthoppers, one by thrips, two by nematodes, and three by soil fungi. Hence, the sample is a good representation of the genetic and biological diversity of plant viruses (57).

For five of these viruses-Beet curly top virus (BCTV), Potato virus $Y$ (PVY), Tomato mosaic virus (ToMV), Tomato spotted wilt virus (TSWV), and Turnip mosaic virus (TuMV) — data on interactions with more than one host were available, and hence we analyzed 35 pathosystems in at least one geographical area each. In addition, different types of resistance have been deployed in some of these 35 pathosystems, and a total of 50 genetic systems were analyzed. We defined resistance factors as those that affect the multiplication of the virus. Tolerance for viruses and resistance to vectors were not considered here.

For each resistance factor and pathosystem, the following information was considered: (i) the host range of the virus, including plants that could be significant as inoculum sources for epidemics in the crop, (ii) the mode of horizontal transmission, (iii) the importance of vertical transmission, through seed or through vegetative multiplication of the crop, (iv) the survival ability of the virus at the site, (v) the dispersal ability of the virus, (vi) the occurrence of genetic exchange in the virus, (vii) inheritance of the resistance factor, (viii) expression of the resistance, (ix) reports of the occurrence of RB isolates, (x) properties of RB isolates, and (xi) the duration of the protection given by the resistance factor. Points (i) to (vi) were used to determine the risk category of each of the three evolutionary factors for each virus and formulate an index of predicted risk. Points (vii) to (xi) were used to try to understand the reason for the durable or transient nature of resistance factors against a certain virus in a particular host.

Information for all pathosystems is provided in Table 2, containing the information listed as points (i) to (vi), and Table 3, containing the information listed as points (vii) to (xi). Four pathosystems, representing different epidemiological and evolutionary strategies, are described next, to illustrate the type of information that was considered in this analysis.

Bean common mosaic virus (BCMV) on bean (Phaseolus vulgaris L.). BCMV is a member of the genus Potyvirus. It has a monopartite, ssRNA genome of messenger sense and is transmitted nonpersistently by several species of aphids and very efficiently (at rates of 30 to 50\%) through seed (94). It has a narrow host range, restricted to members of the Fabaceae, mostly in the genus Phaseolus, but in Europe and the Americas the main inoculum source is contaminated seed (93). Hence survival at the site is low, but long-distance dispersal through infected seed is highly efficient. Analyses of nucleotide sequences of the coat protein (CP) cistron showed that recombination between genetic types is frequent (109). On the basis of these characteristics the predicted combined risk was rated 7 (Table 2).

Two different types of resistance have been used since 1935 to control BCMV. Resistance initially derived from the cultivars Robust and Great Northern is recessive, determined by several loci named $b c$, and results in no infection in resistant plants. Different $b c$ genes and alleles that are overcome by different BCMV pathotypes in a gene-for-gene-like manner have been characterized (93), and protection given by these $b c$ genes has been short-lived, lasting 5 to 20 years $(93,133)$. However, the resistance conferred by allele $b c l$ from Robust, which is effective only against pathotype $\mathrm{P} 0$, has been used in snap bean varieties in the United States with good success for more than 40 years (133). The second resistance was originally found in the cultivar Corbett Refugee and is determined by a single dominant gene, $I$. Resistance conferred by the $I$ gene has been more broadly used and characterized in more detail than resistance conferred by the $b c$ genes. Dominance in $I$ is incomplete, so that a homozygote is immune to BCMV infection, while a heterozygote responds to infection with a hypersensitive reaction (HR), which may result in systemic necrosis (22). Resistance provided by the $I$ gene is overcome by strains in pathotypes $\mathrm{P} 1.1^{2} 2$ and P1.2, first reported in 1963, which cause a systemic necrosis in II plants. Strains causing necrosis of $I$ plants are genetically very different from nonnecrotic BCMV strains (less than $85 \%$ nucleotide sequence identity) and are currently classified as a different potyvirus species, Bean common mosaic necrotic virus (BCMNV). In spite of the existence of RB strains that caused outbreaks in the United States in the late 1980s, the I gene protection has remained effective for several decades, and it is currently widely used, e.g., in more than $75 \%$ of registered bean varieties in Spain (83), in the United States, Western Europe, and Latin America (93). Thus the $I$ gene presents a typical example of durable resistance. On the other hand, the $I$ gene has failed to give good protection in East Africa, where the necrotic strains are prevalent in wild legumes, which seem to be an important source of inoculum for epidemics in bean (120).

Raspberry ringspot virus (RpRSV) on red raspberry (Rubus idaeus L.). RpRSV is a member of the genus Nepovirus, with a bipartite genome of (+)-sense ssRNA. It has a very wide host range, infecting crops and wild plant species in many mono- and dicotyledonous families, and is efficiently seed-transmitted in many of its natural hosts. It is transmitted horizontally by nematode species in the genus Longidorus. The virus does not multiply in its vector, but the nematodes remain viruliferous for up to 9 weeks in fallow soil (49). Hence, the effective size of the virus population may be rated as large. Dispersal is not long-range, and different strains occur in Scotland and England (49). Genetic analyses of different strains suggest that recombinants do not occur or are infrequent (52). Reassortants might occur, but there is evidence of selection for mutual compatibility of RNAs 1 and 2 (48). Predicted risk in this case is rated 5 (Table 2).

Resistance to both the Scottish and the English strains is conferred by a single dominant gene, Irr (60) and is expressed as immunity to vector and graft inoculation. Irr was used in Scotland with excellent results for several decades, until resistant varieties were discontinued in the 1970 s for agronomic reasons (49). RB isolates that are serologically distinguishable (the Lloyd George strain) have been known for a long time (99) but did not become prevalent, because of poor competitive ability in mixed infection with the Scottish strain and poor seed transmission in weeds $(48,60)$. Hence, resistance to RpRSV is an example of durable resistance.

ToMV on tomato (Lycopersicon esculentum Mill.). ToMV is a member of the genus Tobamovirus and has a monopartite, (+)-sense ssRNA genome. It has a narrow natural host range, mostly restricted to members of the Solanaceae, but weeds are not important inoculum sources for infection of tomato (14). The virus is transmitted by plant-to-plant contact but not by vectors. It may persist in dry plant debris for up to 2 years, and in moist soil for about 6 months, hence survival at site would be high. The virus is found in the testae of up to $50 \%$ of the seeds of infected plants, and seedlings are infected during transplant operations, so that in practice ToMV is a seed-transmitted virus (13). However, treatment of seeds to inactivate the virus is common. There is no evidence of recombinants in ToMV, and recombinants are very infrequent in the tobamoviruses (44). The predicted risk is rated 6 (Table 2).

Several resistance factors have been used for the control of ToMV. The first to be used was the incompletely dominant gene Tm1. This gene resulted in lower virus accumulation and was expressed at the protoplast level when infected with isolates of pathotype P0 (130). Cultivars with Tml resistance were first used in glasshouses in the United Kingdom in 1966, but by 1968 the resistance was no longer effective, because of the widespread 
occurrence of RB isolates of pathotype P1, as analyzed in detail in a classic paper by Pelham (105). A single nucleotide change in the viral 126k protein (His984 $\rightarrow$ Tyr) was enough for conversion to pathotype P1 (89). A second resistance gene, Tm2, introduced shortly after, met with the same fate (13). Tm2 confers a HRmediated resistance and is elicited by the viral movement protein (MP). RB isolates (pathotype P2) differ from non-RB strains in two amino acids in the MP (90). An allele of $T m 2, T m 2^{2}$, was introduced into tomato cultivars in the mid-1970s. $T m 2^{2}$ is also elicited by the virus MP and confers a HR. It was overcome by isolates of pathotype $\mathrm{P}^{2}$, and two amino acid changes in the MP were again sufficient to confer the $\mathrm{P} 2^{2}$ phenotype. These changes were in a region of the MP dispensable for cell-to-cell movement (131). However, $\mathrm{P}^{2}$ isolates multiplied poorly in $T m 2^{2}$ plants (37), and this resistance has remained effective for more than 25 years and is still widely used, e.g., in about $80 \%$ of fresh market cultivars in Spain (83).

BCTV on sugar beet (Beta vulgaris L.) and bean. BCTV is the type member of the genus Curtovirus, in the family Geminiviridae, and has a monopartite genome of circular ssDNA. It has a very wide host range, infecting about 300 species in more than 40 dicotyledonous families. It is transmitted by the leafhopper Circulifer tenellus (Baker) in a circulative nonpropagative manner, and it is not seed-transmitted (132). In the arid western regions of North America, where BCTV is most important, the virus and vector overwinter in desert annuals, which are inoculum sources for epidemics in crops each year. The large host range and high rate of survival at the site will result in a large effective population. Dispersal is over a range of 10 to $100 \mathrm{~km}(124,132)$. Several strains of the virus, about $80 \%$ homologous in nucleotide sequence, have been described (121,123). Recombinants among strains occur but appear to be infrequent in populations of the virus $(122,124)$. The predicted risk is rated 7 (Table 2).

Beet curly top was described in California soon after the sugar beet industry was started in the 1870s, and the disease soon became a limiting factor in sugar beet production west of the Rocky Mountains. Breeding for resistance started in 1918. The first resistant variety was released in 1934, and by 1935 it was grown on more than 100,000 acres (33). Resistance of sugar beet to BCTV appears to be quantitative, though its inheritance is not totally understood, and results in lower virus accumulation and less systemic spread in resistant plants (33). The use of resistant varieties resulted in the appearance of severe strains by 1960 and their subsequent increase in frequency in the virus population, until isolates considered severe in 1950 were considered mild in 1970. This process of resistance selecting for more virulent strains has continued, requiring the release of new resistant varieties $(33,122)$. Still, the process is not a fast one, because of balancing selection in winter weeds, which favors strains that are mild in beet, and on resistant beets (50).

Resistance to BCTV has also been bred into common bean, and resistant varieties have been grown in the Columbia River basin since about 1935 (118). Resistance is dominant, conditioned by two epistatic factors, and results in diminished infection. In spite of the different BCTV strains reported in the western United States, and despite changes in the genetic structure of BCTV populations, resistance in beans has been stable for more than 40 years (133).

\section{RESULTS}

Durability of resistance to plant viruses. Resistance is considered durable if no resistance breaking has been reported or if it has been effective for 25 years or more. By this criterion, resistance was durable in two-thirds of the analyzed pathosystems (24 out of 35). RB strains have been reported in 13 of these 24 pathosystems. In 11 pathosystems at least one resistance factor was overcome in less than 25 years, but in five of these cases there was at least one resistance factor that gave durable protection. Thus the 35 analyzed pathosystems can be split into four groups: (i) group D (11 pathosystems in Table 2), in which all deployed resistance factors have been durable, and RB strains have not been reported; (ii) group DRB (13 pathosystems), in which all deployed resistance factors have been durable, but RB strains have occurred; (iii) group ORD (five pathosystems), in which some resistance factors were overcome in less than 25 years, but others have been durable; and (iv) group $\mathrm{O}$ (six pathosystems), in which all deployed resistance factors have been overcome. Table 4 lists the pathosystems in each of the four groups.

Of the 50 resistance factors deployed in 35 pathosystems, 37 were durable and 13 were overcome. RB strains were reported for 19 of the durable resistance factors, but the RB strains did not become prevalent in the virus population, and the protection conferred by the resistance factor remained effective for at least 25 years (Table 3 ).

Relationship between evolutionary risk and durability of resistance. The distribution of predicted risk values was analyzed for the 35 pathosystems in groups $\mathrm{D}, \mathrm{DRB}, \mathrm{ORD}$, and $\mathrm{O}$ by the nonparametric Mann-Whitney test and Monte Carlo simulations, with the same results. The predicted risk was compared among these four groups, and in group combinations that could have biological relevance; e.g., comparison of risk factors in D + DRB

TABLE 4. Pathosystem groups according to durability of resistance $\mathrm{e}^{\mathrm{a}, \mathrm{b}}$

\begin{tabular}{|c|c|c|c|c|}
\hline & Group D & Group DRB & Group ORD & Group O \\
\hline & $\begin{array}{l}\text { BCTV-bean (7) } \\
\text { BLRV-pea (6) } \\
\text { BYDV-barley (6) } \\
\text { CMV-cucumber (8) } \\
\text { GRV-groundnut (4) } \\
\text { PEMV-pea (5) } \\
\text { RSV-rice (7) } \\
\text { SBWMV-wheat (5) } \\
\text { TBRV-raspberry (5) } \\
\text { TMV-tobacco (6) } \\
\text { TuMV-lettuce (9) }\end{array}$ & $\begin{array}{l}\text { ACMV-cassava (8) } \\
\text { BCTV-beet (7) } \\
\text { BNYVV-beet (4) } \\
\text { LMV-lettuce (6) } \\
\text { MNSV-melon (7) } \\
\text { MSV-maize (8) } \\
\text { PSbMV-pea (7) } \\
\text { PVX-potato (4 } \\
\text { PVY-pepper (6) } \\
\text { PVY-tobacco (6) } \\
\text { RpRSV-raspberry (5) } \\
\text { RTSV-rice (8) } \\
\text { TuMV-rapeseed (9) }\end{array}$ & $\begin{array}{l}\text { BCMV-bean (7) } \\
\text { PMMoV-pepper (6) } \\
\text { PVY-potato (7) } \\
\text { SMV-soybean (6) } \\
\text { ToMV-tomato (6) }\end{array}$ & $\begin{array}{l}\text { CLCuV-cotton (8) } \\
\text { RGSV-rice (8) } \\
\text { ToMV-pepper (6) } \\
\text { TSWV-pepper (7) } \\
\text { TSWV-tomato (7) } \\
\text { TYLCV-tomato (9) }\end{array}$ \\
\hline $\begin{array}{l}\text { Mean risk } \\
\text { Median risk }\end{array}$ & $\begin{array}{l}6.18 \\
6.00\end{array}$ & $\begin{array}{l}6.54 \\
7.00\end{array}$ & $\begin{array}{l}6.40 \\
6.00\end{array}$ & $\begin{array}{l}7.50 \\
7.50\end{array}$ \\
\hline
\end{tabular}

a Thirty-five pathosystems are listed, with the predicted risk index in parentheses.

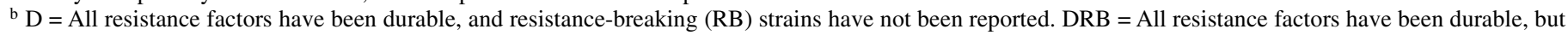
$\mathrm{RB}$ strains occur. ORD $=$ Some resistance factors were overcome in less than 25 years, but others were durable. $\mathrm{O}=\mathrm{All}$ deployed resistance factors have been overcome. 
with those in ORD + O could elucidate differences between systems for which all resistance factors have been durable and those for which some resistance factors have been overcome. We found that the predicted risk for group $\mathrm{O}$ was significantly higher than for the other three groups $(P<0.05)$, while no significant differences were found between the predicted risk for groups D, DRB, and ORD. Hence, according to the predicted risk calculation, pathosystems can be divided into two groups: those for which at least some resistance factor was durable (29 pathosystems, in groups $\mathrm{D}, \mathrm{DRB}$, and ORD) and those for which no resistance was durable (six pathosystems, in group $\mathrm{O}$ ). In a second analysis, the 35 pathosystems were divided into two groups, one consisting of the 24 systems showing durable resistance $(D+D R B)$ and one consisting of the 11 systems in which resistance was broken $(\mathrm{ORD}+\mathrm{O})$. The predicted risk for group $\mathrm{D}+\mathrm{DRB}$ was smaller than that for group ORD $+\mathrm{D}$, with $P=0.10$.

Similar analyses of the relationship between the individual evolutionary factors and the durability of resistance were conducted. The rating for effective population size was significantly higher for the pathosystems in group $\mathrm{O}$ than for the systems in groups $\mathrm{D}$, $\mathrm{DRB}$, and ORD $(P<0.05)$, and no significant differences were found among groups $\mathrm{D}, \mathrm{DRB}$, and ORD. The rating for genetic exchange was lower for group $\mathrm{D}$ than for groups $\mathrm{DRB}, \mathrm{ORD}$, and $\mathrm{O}$ pooled together $(P=0.05)$. The rating for gene flow was lower for the 24 pathosystems in which all resistance factors were durable $(\mathrm{D}+\mathrm{DRB})$ than for the 11 in which at least one factor had been overcome $(\mathrm{ORD}+\mathrm{O})(P=0.07)$.

Hence, the analysis indicates that the durability of resistance reflects the predicted evolutionary potential of the virus.

Relationship between the nature of resistance and its durability. Among the 50 analyzed resistance factors, 32 were monogenic dominant (or incompletely dominant) characters, 10 were monogenic recessive characters, and eight were polygenic. In four of the polygenic cases, resistance was recessive. Resistance in bean to BCTV, in groundnut to Groundnut rosette virus (GRV) and in rice variety Utri Merah to Rice tungro spherical virus (RTSV) was determined by two genes, but in the present analyses we grouped these with the monogenic resistance factors. Eleven $(34 \%)$ of the monogenic dominant, one $(10 \%)$ of the monogenic recessive, and one $(12 \%)$ of the polygenic resistance factors were overcome. Although a higher fraction of the monogenic dominant resistance factors were overcome, no association was found between the genetic basis of the resistance and its durability in a contingency chi-square analysis $(P=0.16$, Fisher's exact test). Similarly, no association was found between the inheritance of the resistance and the occurrence of RB pathotypes $(P=0.86)$.

The expression of the 50 resistance factors differed substantially. Twelve factors conferred immunity or "extreme resistance" to infection; i.e., the virus was not recovered from inoculated plants. Nine factors resulted in resistance to infection. For most pathosystems resistance to infection is immunity to a virus that cannot be mechanically inoculated; i.e., plants are not infected and the virus cannot be recovered from them. But in some cases, e.g., TSWV (21), it seems to refer to escape of infection; i.e., a smaller number of plants are infected, compared with the susceptible controls. Fourteen resistance factors resulted in a HR. For the remaining 15 resistance factors, plants were infected but virus accumulation and systemic spread were lower than in the susceptible controls, because of interference with virus replication or movement. Resistance was overcome for three resistance factors conferring immunity (25\%), two expressed as resistance to infection (22\%), six resulting in a HR (43\%), and two resulting in decreased virus accumulation and systemic spread (13\%). Contingency analyses showed an association between the expression of resistance and its durability $(P=0.05)$ and between the expression of resistance and the occurrence of RB strains $(P=0.10)$, but no significant association was found between any type of resistance expression and its durability or the occurrence of RB strains $(P>0.17)$.
Information on the nature of RB virus strains was available for 27 of the resistance factors. In 14 cases the virulent pathotype was genetically very similar to the nonvirulent strain (more than $98 \%$ similarity of nucleotide sequences), and often a change in a few amino acids was sufficient to cause a change in phenotype. Of these 14 cases, seven led to a breakdown of resistance; the other seven RB strains did not become prevalent in the virus population, so the resistance was stable. In 13 cases the virulent pathotype was a different genetic strain (i.e., less than $95 \%$ similarity of nucleotide sequences) or a different, taxonomically related species in the same genus. Among these, seven overcame resistance, and six did not become prevalent in the virus population. Although there was no association between the nature of the RB strain and its success in the virus population, the high proportion of cases $(48 \%)$ in which the RB strain was an unrelated strain or virus is noteworthy.

\section{DISCUSSION}

A fundamental goal in studies of the evolutionary biology of pathogens is to understand the relationship between the presence and frequency of resistance factors in host populations and the evolution of pathogens to overcome the protection conferred by these resistance factors. This area of research has important practical implications for plant pathology. The use of resistant cultivars is an important control strategy, but it often fails because RB pathogen genotypes increase in frequency. Understanding the factors that favor the evolution of pathogen virulence is essential for devising strategies for breeding and the use of resistance that will result in durable protection. Recent analyses of a large number of cellular plant pathogens indicated that the evolutionary potential of a pathogen could have a major impact on the durability of resistance $(87,88)$. Although the idea that the pathogen's life history may be important in determining the durability of resistance has precedents in the phytopathological literature (e.g., reference 110), McDonald and Linde proposed a theoretical framework leading to a simple model allowing for a quantitative analysis of the relationship between pathogen evolutionary risk (i.e., potential to evolve) and the durability of resistance. In the original analysis, most analyzed cases of resistance were monogenic dominant and followed a gene-for-gene relationship with avirulence in the pathogen. No viruses were considered in the original analyses. In this work we applied the model to the analysis of phytopathogenic viruses.

Viruses differ greatly from cellular pathogens, notably in the nature, size, and expression strategy of their genomes. In addition, resistance deployed to control plant viruses has not been as commonly based on single dominant genes, and gene-for-gene-like relationships between pathogen and host have not been described as frequently for plant viruses as for phytopathogenic fungi and bacteria $(37,38)$. Hence, it could be that the relationship between plant viruses and host resistance is different from that of other plant pathogens. We analyzed 35 pathosystems and 50 resistance factors, on a regional scale. For each system, we obtained information on the population biology of the pathogen, the longevity of the resistance factor or factors used to control it, the inheritance and expression of the resistance, the occurrence of RB pathotypes, and the fate of RB strains in the virus populations. This information was not available for many plant-virus systems. The literature does not usually differentiate between the appearance of RB pathotypes and the actual longevity of a resistance factor. In many cases, unpublished information provided by researchers was critical to clarify this distinction.

The analysis of 50 resistance factors showed no statistically significant association between the inheritance of resistance and its durability or the appearance of RB pathotypes. This result is in contrast with previous analyses that concluded that the appearance of RB pathotypes is more frequent when resistance is monogenic dominant or incompletely dominant, and that monogenic resis- 
tance is overcome more often than other types of resistance (37, 38 ). In previous reports the existence of RB strains was taken as evidence that resistance had been broken, instead of the actual effective life of the resistance factor in the field. We did not find a significant association between the inheritance of resistance and the occurrence of RB pathotypes when the data of Fraser (Table 2 in reference 38$)$ were analyzed $(P=0.311)$. Hence, a relationship between the genetic nature of resistance and its durability is not evident for viruses or for cellular plant pathogens. The expression of resistance seems to play a role in its durability, but our analyses failed to detect a significant association between a particular type of resistance expression (e.g., hypersensitivity or decreased virus accumulation) and durability. In this regard, our results again agree with those of studies of cellular plant pathogens (87), and they differ from previous analyses of plant viruses that concluded that resistance expressed as hypersensitivity is more often overcome than other resistance types (37).

A predicted risk index according to the model proposed earlier (87) was used to explore the relationship between the evolutionary potential of the pathogen and the durability of resistance. This model is obviously an oversimplification of the population biology of pathogens, but detailed analyses of the population structure and evolution of plant viruses are relatively rare (cf. reference 42), and the lack of such analyses precludes the use of more realistic models. In spite of the limitations and assumptions detailed in the section Theory and Approaches, the results of the analysis are statistically and biologically significant. Our results are similar to the previous findings for cellular pathogens (87), in that the evolutionary potential of plant viruses seems to be an important determinant of the durability of resistance. The separate analysis of the three evolutionary factors showed some interesting trends. The systems for which no RB strains have been reported are those in which recombinants or reassortants are relatively rare, suggesting that viruses that admit genetic exchange, and hence are genetically more plastic, are more prone to generate $\mathrm{RB}$ strains than those that do not. The systems in which at least some resistance had been overcome (groups ORD and O) were placed in higher risk categories for gene and genome flow; i.e., viruses in these systems have the ability to migrate longer distances, indicating the relevance of migration in enabling contact between $R B$ strains and resistant plants. Gene flow is also an important factor favoring the breakdown of resistance by cellular plant pathogens (87). The effective population is larger in systems in which all deployed resistance factors have been overcome, which is consistent with the need for a large effective size to allow selection to operate efficiently on the virus population and RB strains to become prevalent in the selected population, leading to the breakdown of resistance.

A major trend apparent from our analyses is that the durability of resistance to plant viruses is far more common than resistance breaking. Even in a large fraction of the pathosystems in which resistance was overcome, some resistance factors were durable (such as BCMV in bean and ToMV in tomato). This is in stark contrast with resistance to plant-pathogenic fungi or bacteria. The durability of resistance to viruses was noted long ago by plant virologists $(50,95)$. Harrison $(50)$ proposed that durability is due to the smaller populations of plant viruses, compared with fungi and bacteria, and speculated that in spite of the high numbers of viruses accumulating within a host, few particles are transmitted between hosts, so that effective population size would be in the range of vector or host population size. This was an important concept, especially at a time when most evolution-oriented virologists stressed the large size of virus populations (28). Our results indicate that effective population size plays a role in overcoming resistance, in agreement with this hypothesis. There have been no serious attempts to estimate the effective population size of any plant virus, and the only (very crude) estimates of which we are aware suggest it would be on the order of the census population of the host plant, i.e., several orders of magnitude smaller than the virus census population (98). It is noteworthy that recent estimates showed that the difference between effective and census population sizes may not be so great for phytopathogenic fungi, and that effective populations are likely to be large enough for selection to operate efficiently $(81,134)$.

Another reason for the durability of resistance to plant viruses is likely to be the lower fitness of RB pathotypes, compared to "wild-type" strains (51). All plant viruses have small genomes in which coding regions are tightly packed and often overlap (57). Plant virus proteins are often multifunctional, and there is ample evidence that different selection pressures, associated with their multiple functions, act on their open reading frames (42). Noncoding regions are small and have important regulatory roles in replication and expression of the virus genome. In such genomes a large fraction of mutations will not be neutral, and it has often been shown that silent mutations and mutations in noncoding regions can result in different phenotypes (42). Hence, mutations resulting in increased virulence to a host genotype would often have a fitness cost. In some experiments, comparative analyses of RB and non-RB pathotypes have shown that the RB genotypes have lower fitness than wild-type strains, because of decreased seed or vector transmission or diminished competitive ability in the crop or in alternate hosts $(48,59,61,73,99)$.

The analyses presented in this paper offer additional support for the hypothesis that a cost of virulence is partially responsible for durable resistance of plants to viruses. First, RB pathotypes have not become prevalent in the virus population in more than half of the 24 pathosystems for which RB pathotypes have been reported, suggesting a decreased fitness of RB strains, compared with wildtype strain. Second, RB pathotypes frequently belong to different genetic strains or different virus species, rather than originating as mutants of the same strain. This suggests that mutations resulting in an overcoming of resistance were selected against and that only widely different genotypes, coming from a different peak of the adaptive landscape, were able to overcome the resistance. It is indeed tempting to speculate that selection would often favor the coevolution of different virus genes, and for some systems there is evidence that selection favors mutual compatibility of cistrons or genomic segments $(36,48)$. Interestingly, viruses in pathosystems for which no RB strains have been reported have significantly lower rates of genetic exchange than the rest, supporting the hypothesis that the fitness cost associated with genetic exchange is one reason for the durability of resistance to plant viruses.

The use of simple models as theoretical frameworks to analyze available information may significantly contribute to understanding complex biological systems. Here we report how this approach provided evidence against some widely accepted views. In spite of limitations imposed by the available information, our analysis uncovered trends that should be reexamined as more information becomes available. We hope that this work will stimulate and orient future research aimed at understanding the relationships between populations of plant viruses and populations of their host plants.

\section{ACKNOWLEDGMENTS}

We want to acknowledge many colleagues for providing unpublished information on resistance-breaking strains and the effectiveness of resistance: J. Ayala and P. García-Benavides on Beet necrotic yellow vein virus in beet; S. Khalid on Cotton leaf curl virus in cotton; J. Abad and B. W. Falk on Cucumber mosaic virus in cucumber; O. Le Gall on Lettuce mosaic virus in lettuce; J. I. Álvarez and M. A. Aranda on Melon necrotic spot virus in melon; M. Ambrose on Pea enation mosaic virus in pea; M. Luis-Arteaga, R. Gil, and F. Ponz on PVY in pepper; J.-L. Verrier on PVY in tobacco; O. Azzam on RTSV in rice; J. Aramburu on TSWV in tomato; G. Anastasio and E. Moriones on Tomato yellow leaf curl virus in tomato; and J. Walsh on TuMV in oilseed rape. We also want to thank José M. Malpica for discussions and advice with statistical analyses. 
Research in the laboratory of FGA was in part supported by grant AGL2002-00743 from Ministerio de Ciencia y Tecnología, Spain. Research in the laboratory of BAM was supported in part by grant 3156874.99 from the Swiss National Science Foundation.

\section{LITERATURE CITED}

1. Ali, M. 1997. Breeding cotton varieties for resistance to cotton leaf curl virus. Pak. J. Phytopathol. 9:1-7.

2. Azzam, O., and Chancellor, T. C. B. 2002. The biology, epidemiology and management of rice tungro disease in Asia. Plant Dis. 86:88-100.

3. Azzam, O., Imbe, T., Ikeda, R., Nath, P. D., and Coloquio, E. 2001. Inheritance of resistance to rice tungro spherical virus in a near-isogenic line derived from Utri Merah and in rice cultivar TKM6. Euphytica 122: 91-97.

4. Azzam, O., Yambao, M. L. M., Muhsin, M., McNally, K. L., and Umadhay, K.-M. L. 2000. Genetic diversity of rice tungro spherical virus in tungro-endemic provinces of the Philippines and Indonesia. Arch. Virol. 145:1183-1197.

5. Berzal-Herranz, A., de la Cruz, A., Tenllado, F., Díaz-Ruiz, J. R., López, L., Sanz, A. I., Vaquero, C., Serra, M. T., and García-Luque, I. 1995. The Capsicum $\mathrm{L}^{3}$ gene-mediated resistance against the tobamoviruses is elicited by the coat protein. Virology 209:498-505.

6. Biffen, R. H. 1905. Mendel's law of inheritance and wheat breeding. J. Agric. Sci. 1:4-48.

7. Blancard, D., Ano, G., and Cailleteau, B. 1995. Etude du pouvoir pathogène d'isolats de PVY sur tabac: Proposition d'une classification intégrant la résistance à la nécrose. Ann. Tab. 2:43-50.

8. Blanco-Urgoiti, B., Sánchez, F., Pérez de San Román, C., Dopazo, J., and Ponz, F. 1998. Potato virus Y group C isolates are a homogeneous pathotype but two different genetic strains. J. Gen. Virol. 79:2037-2042.

9. Blanco-Urgoiti, B., Tribodet, M., Leclere, S., Ponz, F., Pérez de San Román, C., Legorburu, F. J., and Kerlan, C. 1998. Characterization of potato potyvirus Y (PVY) isolates from seed potato batches: Situation of the NTN, Wilga and Z isolates. Eur. J. Plant Pathol. 104:811-819.

10. Bosque-Pérez, N. A. 2000. Eight decades of Maize streak virus research. Virus Res. 71:107-121.

11. Boukema, I. W. 1980. Allelism of genes controlling resistance to TMV in Capsicum. Euphytica 29:433-439.

12. Briddon, R. W., and Markham, P. G. 2000. Cotton leaf curl virus disease. Virus Res. 71:151-159.

13. Broadbent, L. 1976. Epidemiology and control of tomato mosaic virus. Annu. Rev. Phytopathol. 14:75-96.

14. Brunt, A. A. 1986. Tomato mosaic virus. Pages 181-204 in: The Plant Viruses. 2. The Rod-Shaped Plant Viruses. M. H. V. Van Regenmortel and H. Fraenkel-Conrat, eds. Plenum Press, New York.

15. Burnett, P. A., and Plumb, R. T. 1998. Present status of controlling barley yellow dwarf virus. Pages 448-458 in: Plant Virus Disease Control. A. Hadidi, R. K. Khetarpal, and H. Koganezawa, eds. American Phytopathological Society, St. Paul, MN.

16. Cabauatan, P. Q., Cabunagan, R. C., and Koganezawa, H. 1995. Biological variants of rice tungro viruses in the Philippines. Phytopathology 85:77-81.

17. Chao, L. 1988. Evolution of sex in RNA viruses. J. Theor. Biol. 133:99112.

18. Chen, J., MacFarlane, S. A., and Wilson, T. M. A. 1995. Effect of cultivation temperature on the spontaneous development of deletions in soilborne wheat mosaic furovirus RNA2. Phytopathology 85:299-306.

19. Chen, P., Buss, G. R., Roane, C. W., and Tolin, S. A. 1991. Allelism among genes for resistance to soybean mosaic virus in strain-differential soybean cultivars. Crop Sci. 31:305-309.

20. Cho, E.-K., and Goodman, R. M. 1979. Strains of soybean mosaic virus: Classification based on virulence in resistant soybean cultivars. Phytopathology 69:467-470.

21. Cho, J., Mau, R. F. L., Pang, S.-Z., Wang, M., Gonsalves, C., Watterson, J., Custer, D. M., and Gonsalves, D. 1998. Approaches for controlling tomato spotted wilt virus. Pages 547-564 in: Plant Virus Disease Control. A. Hadidi, R. K. Khetarpal, and H. Koganezawa, eds. American Phytopathological Society, St. Paul, MN.

22. Collmer, C. W., Marston, M. F., Taylor, J. G., and Jahn, M. 2000. The $I$ gene of bean: A dosage-dependent allele conferring extreme resistance, hypersensitive resistance, or spreading vascular necrosis in response to the potyvirus Bean common mosaic virus. Mol. Plant-Microbe Interact. 13:1266-1270.

23. Cruz, A. de la, López, L., Tenllado, F., Díaz-Ruiz, J. R., Sanz, A. I., Vaquero, C., Serra, M. T., and García-Luque, I. 1997. The coat protein is required for the elicitation of the Capsicum $\mathrm{L}^{2}$ gene-mediated resistance against the tobamoviruses. Mol. Plant-Microbe Interact. 10:107-113.

24. D'Arcy, C. 1997. Barley yellow dwarf. Pages 59-61 in: Compendium of
Barley Diseases. 2nd ed. D. E. Mathre, ed. American Phytopathological Society, St Paul, MN.

25. Deom, C. M., Naidu, R. A., Chiyembekeza, A. J., Ntare, B. R., and Subrahmanyam, P. 2000. Sequence diversity within the three agents of groundnut rosette disease. Phytopathology 90:214-219.

26. Díaz, J. A., Nieto, C., Moriones, E., and Aranda, M. A. 2002. Spanish Melon necrotic spot virus isolate overcomes the resistance conferred by the recessive $n s v$ gene of melon. Plant Dis. 86:694.

27. Dinant, S., and Lot, H. 1992. Lettuce mosaic virus: A review. Plant Pathol. 41:529-542.

28. Domingo, E., and Holland, J. J. 1988. High error rates, population equilibrium and evolution of RNA replication systems. Pages 3-36 in:. RNA Genetics. Vol. 3, Variability of RNA Genomes. E. Domingo, J. J. Holland, and P. Ahlquist, eds. CRC Press, Boca Raton, FL.

29. Drake, J. W., Charlesworth, B., Charlesworth, D., and Crow, J. F. 1998. Rates of spontaneous mutation. Genetics 148:1667-1686.

30. Drijfhout, E. 1968. Testing for pea leafroll virus and inheritance of resistance in peas. Euphytica 17:224-235.

31. Drumm Meyers, L., Sherwood, J. L., Siegerist, W. C., and Hunger, R. M. 1993. Temperature-influenced virus movement in expression of resistance to soilborne wheat mosaic virus in hard red winter wheat (Triticum aestivum). Phytopathology 83:548-551.

32. Dubey, S. N., Brown, C. M., and Hooker, A. L. 1970. Inheritance of field reaction to soil-borne wheat mosaic virus. Crop Sci. 10:93-95.

33. Duffus, J. E., and Skoyen, I. O. 1977. Relationship of age of plants and resistance to a severe isolate of beet curly top virus. Phytopathology 67: 151-154.

34. Efron, Y., Kim, S. K., Fajemisin, J. M., Mareck, J. H., Tang, C. Y., Dabrowski, Z. T., Rossel, H. W., Thottapilly, G., and Buddenhagen, I. W. 1989. Breeding for resistance to Maize streak virus: A multidisciplinary team approach. Plant Breed. 103:1-36.

35. Fauquet, C., and Fargette, D. 1990. African cassava mosaic virus: Etiology, epidemiology, and control. Plant Dis. 74:404-411.

36. Fraile, A., Alonso-Prados, J. L., Aranda, M. A., Bernal, J. J., Malpica, J. M., and García-Arenal, F. 1997. Genetic exchange by recombination or reassortment is infrequent in natural populations of a tripartite RNA plant virus. J. Virol. 71:934-940.

37. Fraser, R. S. S. 1990. The genetics of resistance to plant viruses. Annu. Rev. Phytopathol. 28:179-200.

38. Fraser, R. S. S. 1992. The genetics of plant virus interactions: Implications for plant breeding. Euphytica 63:175-185.

39. Frost, S. D. W., Dumaurier, M.-J., Wain-Hobson, S., and Leigh Brown, A. J. 2001. Genetic drift and within host metapopulation dynamics of HIV-1 infection. Proc. Natl. Acad. Sci. USA 98:6975-6980.

40. Furumoto, W., and Mickey, R. 1967. A mathematical model for the infectivity-dilution curve of tobacco mosaic virus: Experimental tests. Virology 32:216-223.

41. García-Arenal, F., Escriu, F., Aranda, M. A., Alonso-Prados, J. L., Malpica, J. M., and Fraile, A. 2000. Molecular epidemiology of Cucumber mosaic virus and its satellite RNA. Virus Res. 71:1-8.

42. García-Arenal, F., Fraile, A., and Malpica, J. M. 2001. Variability and genetic structure of plant virus populations. Annu. Rev. Phytopathol. 39: 157-186.

43. Ghanim, M., Morin, S., Zeidan, M., and Czosnek, H. G. 1998. Evidence for transovarial transmission of tomato yellow leaf curl virus by its vector, the whitefly Bemisia tabaci. Virology 240:295-303.

44. Gibbs, A. 1999. Evolution and origin of tobamoviruses. Philos. Trans. R. Soc. London B 354:593-602.

45. Gooding, G. V. 1986. Tobacco mosaic virus: Epidemiology and control. Pages 133-152 in: The Plant Viruses. 2. The Rod-Shaped Plant Viruses. M. H. V. Van Regenmortel and H. Fraenkel-Conrat, eds. Plenum Press, New York.

46. Hajimorad, M. R., and Hill, J. H. 2001. Rsv1-mediated resistance against Soybean mosaic virus-N is hypersensitive response-independent at inoculation site, but has the potential to initiate a hypersensitive responselike mechanism. Mol. Plant-Microbe Interact. 14:587-598.

47. Hampton, R. O. 1983. Pea leaf roll in northwestern U.S. pea seed production areas. Plant Dis. 67:1306-1310.

48. Hanada, K., and Harrison, B. D. 1977. Effects of virus genotype and temperature on seed transmission of nepoviruses. Ann. Appl. Biol. 85:79-92.

49. Harrison, B. D. 1977. Ecology and control of viruses with soil-inhabiting vectors. Annu. Rev. Phytopathol. 15:331-360.

50. Harrison, B. D. 1981. Plant virus ecology: Ingredients, interactions and environmental influences. Ann. Appl. Biol. 99:195-209.

51. Harrison, B. D. 2002. Virus variation in relation to resistance-breaking in plants. Euphytica 124:181-192.

52. Harrison, B. D., Murant, A. F., Mayo, M. A., and Roberts, I. M. 1974. Distribution of determinants for symptom production, host range and nematode transmissibility between the two RNA components of rasp- 
berry ringspot virus. J. Gen. Virol. 22:233-247.

53. Heijbroek, W., Musters, P. M. S., and Schoone, A. H. L. 1999. Variation in pathogenicity and multiplication of beet necrotic yellow vein virus (BNYVV) in relation to resistance of sugar beet cultivars. Eur. J. Plant Pathol. 105:397-405.

54. Hibi, T., and Furuki, I. 1985. Melon necrotic spot virus. No. 302 in: Descriptions of Plant Viruses. Commonw. Mycol. Inst./Assoc. Appl. Biol., Kew, England.

55. Hibino, H. 1996. Biology and epidemiology of rice viruses. Annu. Rev. Phytopathol. 34:249-274.

56. Hibino, H., Cabauatan, P. Q., Omura, T., and Tsuchizaki, T. 1985. Rice grassy stunt virus strain causing tungrolike symptoms in the Philippines. Plant Dis. 69:538-541.

57. Hull, R. 2001. Matthews' Plant Virology. Academic Press, San Diego, CA.

58. Jenner, C. E., and Walsh, J. A. 1996. Pathotype variation in turnip mosaic virus with special reference to European isolates. Plant Pathol. 45: 848-856.

59. Jenner, C. E., Wang, X., Ponz, F., and Walsh, J. A. 2002. A fitness cost for Turnip mosaic virus to overcome host resistance. Virus Res. $86: 1-6$.

60. Jennings, D. L. 1964. Studies on the inheritance in the red raspberry of immunities from three nematode-borne viruses. Genetica 35:152164.

61. Johansen, I. E., Keller, K. E., Dougherty, W. G., and Hampton, R. O. 1996. Biological and molecular properties of a pathotype P-1 and a pathotype P-4 isolate of pea seed-borne mosaic virus. J. Gen. Virol. 77: 1329-1333.

62. Johansen, I. E., Lund, O.-S., Hjuslager, C. K., and Laursen, J. 2001. Recessive resistance in Pisum sativum and potyvirus pathotype resolved in a gene-for-cistron correspondence between host and virus. J. Virol. 75: 6609-6614.

63. Jones, R. A. C. 1982. Breakdown of potato virus X resistance gene Nx: Selection of a group four strain from strain group three. Plant Pathol. 31:325-331.

64. Jones, R. A. C. 1990. Strain group specific and virus specific hypersensitive reactions to infection with potyviruses in potato cultivars. Ann. Appl. Biol. 117:93-105.

65. Khetarpal, R. K., Maisonneuve, B., Maury, Y., Chalhoub, B., Dinant, S., Lecoq, H., and Varma, A. 1998. Breeding for resistance to plant viruses. Pages 14-32 in: Plant Virus Disease Control. A. Hadidi, R. K. Khetarpal, and H. Koganezawa, eds. American Phytopathological Society, St. Paul, $\mathrm{MN}$.

66. Khetarpal, R. K., and Maury, Y. 1987. Pea seed-borne mosaic virus: A review. Agronomie 7:215-224.

67. Khurana, S. M. P., and Garg, I. D. 1998. Present status of controlling mechanically and non-persistently aphid-transmitted potato viruses. Pages 593-615 in: Plant Virus Disease Control. A. Hadidi, R. K. Khetarpal, and H. Koganezawa, eds. American Phytopathological Society, St. Paul, MN.

68. Khush, G. S., and Ling, K. C. C. 1974. Inheritance of resistance to grassy stunt virus and its vector in rice. J. Hered. 65:134-136.

69. Kisimoto, R., and Yamada, Y. 1998. Present status of controlling rice stripe virus. Pages 470-483 in: Plant Virus Disease Control. A. Hadidi, R. K. Khetarpal, and H. Koganezawa, eds. American Phytopathological Society, St. Paul, MN.

70. Koenig, R., Lüddecke, P., and Haeberlé, A. M. 1995. Detection of beet necrotic yellow vein virus strains, variants and mixed infections by examining single-stranded conformation polymorphisms of immunocapture RT-PCR products. J. Gen. Virol. 76:2051-2055.

71. Koganezawa, H. 1998. Present status of controlling rice tungro virus. Pages 459-469 in: Plant Virus Disease Control. A. Hadidi, R. K. Khetarpal, and H. Koganezawa, eds. American Phytopathological Society, St. Paul, MN.

72. Kohnen, P. D., Johansen, I. E., and Hampton, R. O. 1995. Characterization and molecular detection of the $\mathrm{P} 4$ pathotype of pea seedborne mosaic potyvirus. Phytopathology 85:789-793.

73. Krause-Sakate, R., Le Gall, O., Fakhfakh, H., Peypelut, M., Marrakchi, M., Varveri, C., Pavan, M. A., Souche, S., Lot, H., Murilo Zerbini, F., and Candresse, T. 2002. Molecular and biological characterization of Lettuce mosaic virus (LMV) isolates reveals a distinct and widespread type of resistance-breaking isolate: LMV-Most. Phytopathology 92:563572.

74. Kruse, M, Koenig, R., Hoffmann, A., Commandeur, U., Solovyev, A. G., Savenko, I., and Burgmeister, W. 1994. Restriction fragment length polymorphism analysis of reverse transcription-PCR products reveals the existence of two major strain groups of beet necrotic yellow vein virus. J. Gen. Virol. 75:1835-1842.

75. Kyle, M. M., and Palloix, A. 1997. Proposed revision of nomenclature for potyvirus resistance genes in Capsicum. Euphytica 97:183-188.
76. Larsen, R. C. 2001. Bean leaf roll virus. Pages 34-36 in: Compendium of Pea Diseases. 2nd ed. J. M. Kraft and F. L. Pfleger, eds. American Phytopathological Society, St. Paul, MN.

77. Larsen, R. C. 2001. Pea enation mosaic virus. Page 36 in: Compendium of Pea Diseases. 2nd ed. J. M. Kraft and F. L. Pfleger, eds. American Phytopathological Society, St. Paul, MN.

78. Legg, J. P. 1999. Emergence, spread and strategies for controlling the pandemic of cassava mosaic virus disease in east and central Africa. Crop. Prot. 18:627-637.

79. Legg, J. P., and Thresh, J. M. 2000. Cassava mosaic virus disease in East Africa: A dynamic disease in a changing environment. Virus Res. 71:135-149.

80. Leigh-Brown, A. J. 1997. Analysis of HIV-1 env gene sequences reveals evidence for a low effective number in the viral population. Proc. Natl. Acad. Sci. USA 94:1862-1865.

81. Leslie, J. F., and Klein, K. K. 1996. Female fertility and mating type effects on effective population size and evolution of filamentous fungi. Genetics 144:557-567.

82. Malpica, J. M., Fraile, A., Moreno, I., Obies, C. I., Drake, J. W., and García-Arenal, F. 2002. The rate and character of spontaneous mutation in an RNA virus. Genetics 162:1505-1511.

83. Marín-Rodríguez, J. 2000. Vademecum de variedades hortícolas. Portagrano, Almería, Spain.

84. Martin, D. P., Willment, J. A., Billharz, R., Velders, R., Odhiambo, B., Njuguna, J., James, D., and Rybicki, E. P. 2001. Sequence diversity and virulence in Zea mays of Maize streak virus isolates. Virology 288:247255.

85. Mastari, J., Lapierre, H., and Dessens, J. T. 1998. Asymmetrical distribution of barley yellow dwarf virus PAV variants between host plant species. Phytopathology 88:818-821.

86. Maule, A. J., Boulton, M., and Wood, K. R. 1980. Resistance of cucumber protoplasts to cucumber mosaic virus: A comparative study. J. Gen. Virol. 51:271-279.

87. McDonald, B. A., and Linde, C. 2002. Pathogen population genetics, evolutionary potential, and durable resistance. Annu. Rev. Phytopathol. 40:349-379.

88. McDonald, B. A., and Linde, C. 2002. Pathogen population genetics and the durability of resistance. Euphytica 124:163-180.

89. Meshi, T., Motoyoshi, F., Adachi, A., Watanabe, Y., Takamatsu, N., and Okada, Y. 1988. Two concomitant base substitutions in the putative replicase genes of tobacco mosaic virus confer the ability to overcome the effects of a tomato resistance gene, Tm-1. EMBO J. 7:1575-1581.

90. Meshi, T., Motoyoshi, F. Maeda, T., Yoshikawa, S., Watanabe, Y., and Okada, Y. 1989. Mutations in the tobacco mosaic virus 30-kd protein gene overcome Tm-2 resistance in tomato. Plant Cell 1:515-522.

91. Miranda, G. J., Azzam, O., and Shirako, Y. 2000. Comparison of nucleotide sequences between northern and southern Philippine isolates of rice grassy stunt virus indicates occurrence of natural genetic reassortment. Virology 266:26-32

92. Monci, F., Sánchez-Campos, S., Navas-Castillo, J., and Moriones, E. 2002. A natural recombinant between, the geminiviruses Tomato yellow leaf curl Sardinia virus and Tomato yellow leaf curl virus exhibits a novel pathogenic phenotype and is becoming prevalent in Spanish populations. Virology 303:317-326.

93. Morales, F. J. 1998. Present status of controlling bean common mosaic virus. Pages 524-533 in: Plant Virus Disease Control. A. Hadidi, R. K. Khetarpal, and H. Koganezawa, eds. American Phytopathological Society, St. Paul, MN.

94. Morales, F. J., and Bos, L. 1988. Bean common mosaic virus. No. 337 in: Descriptions of Plant Viruses. Commonw. Mycol. Inst./Assoc. Appl. Biol., Kew, England.

95. Moreira, A., Jones, R. A. C., and Fribourg, C. E. 1980. Properties of a resistance-breaking strain of potato virus X. Ann. Appl. Biol. 95:93103.

96. Moriones, E., and Navas-Castillo, J. 2000. Tomato yellow leaf curl virus, an emerging virus complex causing epidemics worldwide. Virus Res. 71:123-134.

97. Moury, B., Morel, C., Johansen, E., and Jacquemond, M. 2002. Evidence for diversifying selection in Potato virus $\mathrm{Y}$ and in the coat protein of other potyviruses. J. Gen. Virol. 83:2563-2573.

98. Moya, A., Rodríguez-Cerezo, E., and García-Arenal, F. 1993. Genetic structure of natural populations of the plant RNA virus tobacco mild green mosaic virus. Mol. Biol. Evol. 10:449-456.

99. Murant, A. F., Taylor, C. E., and Chambers, J. 1968. Properties, relationships and transmission of a strain of raspberry ringspot virus infecting raspberry cultivars immune to the common Scottish strain. Ann. Appl. Biol. 61:175-186.

100. Naidu, R. A., Kimmins, F. M., Deom, C. M., Subrahmanyam, P., Chiyembekeza, A. J., and van der Merwe, P. J. A. 1999. Groundnut rosette: A virus disease affecting groundnut production in sub-Saharan Africa. 
Plant Dis. 83:700-709.

101. Nigam, S. N., and Ock, K. R. 1990. Inheritance of resistance to groundnut rosette virus in groundnut (Arachis hypogaea L.). Ann. Appl. Biol. 117:553-560

102. Oshima, K., Yamaguchi, Y., Hirota, R., Hamamoto, T., Tomimura, K., Tan, Z. Y., Sano, T., Azuhata, F., Walsh, J. A., Fletcher, J., Chen, J., Gera, A., and Gibbs, A. 2002. Molecular evolution of Turnip mosaic virus: Evidence of host adaptation, genetic recombination and geographical spread. J. Gen. Virol. 83:1511-1521.

103. Padgett, H. S., and Beachy, R. N. 1993. Analysis of a tobacco mosaic virus strain capable of overcoming $\mathrm{N}$ gene-mediated resistance. Plant Cell 5:577-586.

104. Palukaitis, P., Roossinck, M. J., Dietgen, R. G., and Francki, R. I. B. 1992. Cucumber mosaic virus. Adv. Virus Res. 41:281-348.

105. Pelham, J. Fletcher, J. T., and Hawkings, J. H. 1970. The establishment of a new strain of tobacco mosaic virus resulting from the use of resistant varieties of tomato. Ann. Appl. Biol. 65:293-297.

106. Pirone, T. P., and Thornbury, D. W. 1988. Quantity of virus required for aphid transmission of a potyvirus. Phytopathology 78:104-107.

107. Pita, J. S., Fondong, V. N., Sangaré, A., Otim-Nape, G. W., Ogwal, S., and Fauquet, C. M. 2001. Recombination, pseudorecombination and synergism of geminiviruses are determinant keys to the dynamics of severe cassava mosaic disease in Uganda. J. Gen. Virol. 82:655-665.

108. Redondo, E., Krause-Sakate, R., Yang, S.-J., Lot, H., Le Gall, O., and Candresse, T. 2001. Lettuce mosaic virus pathogenicity determinants in susceptible and tolerant lettuce cultivars map to different regions of the viral genome. Mol. Plant-Microbe Interact. 14:804-810.

109. Revers, F., Le Gall, O., Candresse, T., Leromacer, M., and Dunez, J. 1996. Frequent occurrence of recombinant potyvirus isolates. J. Gen. Virol. 77:1953-1965.

110. Robinson, R. A. 1971. Vertical resistance. Rev. Appl. Mycol. 50:233239.

111. Rodier, A., Assié, J., Marchand, J. L., and Hervé, Y. 1995. Breeding maize lines for complete and partial resistance to maize streak virus (MSV). Euphytica 81:57-70.

112. Rodríguez-Cerezo, E., Moya, A., and García-Arenal, F. 1989. Variability and evolution of the plant RNA virus pepper mild mottle virus. J. Virol. 63:2198-2203.

113. Roggero, P., Masenga, V., and Tavella, L. 2002. Field isolates of Tomato spotted wilt virus overcoming resistance in pepper and their spread to other hosts in Italy. Plant Dis. 86:950-954.

114. Romero, A., Blanco-Urgoiti, B., Soto, M. J., Fereres, A., and Ponz, F. 2001. Characterization of typical pepper-isolates of PVY reveals multiple pathotypes within a single genetic strain. Virus Res. 79:71-80.

115. Sanz, A. I., Fraile, A., García-Arenal, F., Zhou, X., Robinson, D. J., Khalid, S., Butt, T., and Harrison, B. D. 2001. Multiple infection, recombination, and genome relationships among begomovirus isolates found in cotton and other plants in Pakistan. J. Gen. Virol. 81:18391849.

116. Schroeder, W. T., and Barton, D. W. 1958. The nature and inheritance of resistance to the pea enation mosaic virus in garden pea, Pisum sativum L. Phytopathology 48:628-632.

117. Shirako, Y., Suzuki, N., and French, R. C. 2000. Similarity and diver- gence among viruses in the genus Furovirus. Virology 270:201-207.

118. Silvernagel, M. J. 1965. Differential tolerance to curly top in some snap bean varieties. Plant Dis. Rep. 49:475-477.

119. Slykhuis, J. T. 1976. Virus and virus-like diseases of cereal crops. Annu. Rev. Phytopathol. 14:189-210.

120. Spence, N. J., and Walkey, D. G. A. 1995. Variation for pathogenicity among isolates of bean common mosaic virus in Africa and a re-interpretation of the genetic relationship between cultivars of Phaseolus vulgaris and pathotypes of BCMV. Plant Pathol. 44:527-546.

121. Stenger, D. C. 1994. Complete nucleotide sequence of the hypervirulent $\mathrm{CFH}$ strain of beet curly top virus. Mol. Plant-Microbe Interact. 7:154-157.

122. Stenger, D. C. 1995. Genotypic variability and the occurrence of less than genome-length viral DNA forms in a field population of beet curly top geminivirus. Phytopathology 85:1316-1322.

123. Stenger, D. C., Carbonaro, D., and Duffus, J. E. 1990. Genomic characterization of phenotypic variants of beet curly top virus. J. Gen. Virol. 71:2211-2215.

124. Stenger, D. C., and McMahon, C. L. 1997. Genotypic diversity of beet curly top virus populations in the western United States. Phytopathology 87:737-744.

125. Tamada, T. 1975. Beet necrotic yellow vein virus. No. 144 in: Descriptions of Plant Viruses. Commonw. Mycol. Inst./Assoc. Appl. Biol., Kew, England

126. Tenllado, F., García-Luque, I., Serra, M. T., and Díaz-Ruiz, J. R. 1997. Pepper resistance-breaking tobamoviruses: Can they co-exist in a single pepper plant? Eur. J. Plant Pathol. 103:235-243.

127. van Vloten-Doting, L., and Bol, J. F. 1988. Variability, mutant selection, and mutant stability in plant RNA viruses. Pages 37-51 in: RNA Genetics. Vol. 3, Variability of RNA Genomes. E. Domingo, J. J. Holland, and P. Ahlquist, eds. CRC Press, Boca Raton, FL.

128. Walsh, J. A., and Jenner, C. E. 2002. Turnip mosaic virus and the quest for durable resistance. Mol. Plant Pathol. 3:289-300.

129. Wangai, A. W., Pappu, S. S., Pappu, H. R., Deom, C. M., and Naidu, R. A. 2001. Distribution and characteristics of groundnut rosette disease in Kenya. Plant Dis. 85:470-474.

130. Watanabe, Y., Kishibayashi, N., Motoyoshi, F., and Okada, Y. 1987. Characterization of $\mathrm{Tm}-1$ gene action on replication of common isolates and a resistance breaking isolate of tobacco mosaic virus. Virology 161: 527-536.

131. Weber, H., and Pfitzner, A. J. P. 1998. Tm $2^{2}$ resistance in tomato requires recognition of the carboxy terminus of the movement protein of tomato mosaic virus. Mol. Plant-Microbe Interact. 11:498-503.

132. Wisler, G. C., and Duffus, J. E. 2000. A century of plant virus management in the Salinas Valley of California, "East of Eden." Virus Res. 71: 161-169.

133. Zaumeyer, W. J., and Meiners, J. P. 1975. Disease resistance in beans. Annu. Rev. Phytopathol. 13:313-334.

134. Zhan, J., Mundt, C. C., and McDonald, B. A. 2001. Using restriction fragment length polymorphisms to assess temporal variation and estimate the number of ascospores that initiate epidemics in field populations of Mycosphaerella graminicola. Phytopathology 91:10111017. 